\title{
Teenagers Language Politeness Strategy on Social Media WhatsApp Based on Level of Education
}

\author{
Riska Amalia Hafid \\ hra21f@student.unhas.ac.id \\ Hasanuddin University, Indonesia \\ Serliana (Corresponding Author) \\ serliana21f@student.unhas.ac.id \\ Hasanuddin University, Indonesia \\ Gusnawaty \\ gusnawaty@unhas.ac.id \\ Hasanuddin University, Indonesia \\ Ikhwan M. Said \\ ikhwansaid@unhas.ac.id \\ Hasanuddin University, Indonesia
}

\begin{abstract}
Language politeness in social media is still often ignored. The article aims to describe teenagers' politeness strategies in social media conversations, especially in the WhatsApp group of junior high schools, senior high schools, and colleges. The research was quantitative and qualitative descriptive, and the population was complete sentences in WhatsApp group conversations. The period of recording the conversation with each group is during September 2021. The data collection technique is by exporting the conversation data to Ms. Words. The data were arranged based on the entry date, then coded using Brown \& Levinson's politeness theory. The interpretation of the data classification results used the approach of Makassar's cultural perspective. The findings showed that in social media WhatsApp, the teenagers talked more frequently used three kinds of politeness strategies. 1) Bald on record involving questions, commands, and requests. Teenagers use this strategy from three-level of education. 2) Positive strategies involve jokes, identity, and paying attention. The college and high schools teenagers use jokes and identity. However, paying attention's strategy is just used by college teenagers. 3) Negative strategies include apologies, be-thankful, and questions. College and high schools teenagers use the apology and thank strategies. Nevertheless, teenagers from the high school level only used negative politeness in asking questions. In conclusion, the level of education of teenagers determines the use of politeness strategy in social media. The implication is that teachers and stakeholders pay more attention to students' language politeness building, especially in speaking politely to others, so their interaction is harmonious with their communities.
\end{abstract}

Keywords: Character education; WhatsApp; politeness strategies; education level. 


\section{A. INTRODUCTION}

Recently, Language politeness in social media has been facing threat acts. Therefore, many researchers are interested in investigating them. Researchers have researched and found various cases of it. For example, the WhatsApp application's conversation among lecturers and administrative staff used most utterances to represent obedience to the politeness maxim (Chandra, 2021). The people interacting on the WHO Instagram's official account used four politeness strategies in their utterances (Mulyana, 2021). Also, most SMP Negeri 3 Babat students used favorable terms of the maxims of generosity and facial expression at WhatsApp interaction (Yono, 2021). Then, Husna \& Arief (2020) found that students' most widely used negative politeness strategy to their lecturers.

Furthermore, Purnamasari, Nurmansyah, \& Fitriani (2021) found that student utterance in offline learning ignores differences in social status and distance or intimacy because it maximizes the face threat of the interlocutor. On the other hand, while online learning through Whatsapp, students try to respect or save the face of the interlocutor because of differences in social status and distance. Even, Yaqien \& Haeri (2021) found that the highest level of dominance of students in the group was more likely to use the maxim of sympathy in the form of attention, affection, and motivation. Besides. Setiawan's research (2020) found that many students still lay in placing appropriate utterances that must be said to lecturers and what utterances to their peers. Also, some students seem to organize and dictate or manage the lecturer's schedule.

As Yus (2011:256) stated, politeness is typical and essential in internet-mediated communication, and it is typically called netiquette (from internet/net and etiquette). However, this internet-mediated communication or social media interaction is becoming challenging. Because internet-mediated communication lacks physical co-presence and contextual support, leading to a lack of self-control and parallel lack of linguistic markers of politeness (Yus, 2011:262) and politeness strategies (Brown \& Levinson, 1987). Furthermore, according to Kasper (2007) Furthermore, according to Gunarwan (2007: 85), the speaker needs to expand their politeness strategy by answering three questions. First, is the purpose that the speaker wants to express that can threaten the face of the interlocutor? Second, what is the relative weight of the force of speech to be expressed in the culture in question? Finally, does the speaker have the pragmatic competence to 
reduce the impact of the face-threatening act so that what comes out of the speaker's mouth is an action that protects the face, which can be interpreted as politeness?

Generally, humans interact by using social media. This has become a habit in everyday life because social media is a medium that allows users to represent themselves and interact, work together, share, communicate with other users to form virtual social bonds (Nasrullah, 2015). Therefore, the use of social media completely revolutionized the way information is shared and consumed and has become a relevant part of government agencies and companies (Kaplan \& Haenlein, 2010). The social media that are widely used are YouTube, Facebook, Instagram, Twitter, Line, Pinterest, WhatsApp, Fb Messenger, Tik-Tok (Douyin), Reddit, LinkedIn, Skype, and Snapchat. The social media that is most widely used interactively mostly is WhatsApp. The latest research reveals that the population of social media users uses Whatsapp, $87,7 \%$ of the total population in Indonesia (Hootsuite, 2021).

Although considerable research has been devoted to language politeness in social media, relatively little attention has been paid to comparing teenagers' language politeness strategies from their education level in the WhatsApp group. At the same time, it is essential to research this problem because politeness is a social connection expression and part of efforts to establish and maintain social relations (Brown \& Levinson, 1987). Moreover, at the same time, politeness manifests local wisdom and local culture.

The purpose of this article is to describe the teenager's language politeness strategies on Whatsapp social media based on their education level and to find and classify language politeness strategies by each level of education. The researcher used Brown and SC Levinson's (Brown \& Levinson, 1987) five politeness strategies and Makassar's culture perspectives as indicators. The five politeness strategies are: 1) bald on record. The speaker used this strategy to convey their meaning as efficiently as possible. Both parties know this situation, so face protection is no longer needed; 2) positive politeness strategies. The politeness is maintained positive face politeness of speaker. It means a positive face refers to a person's self-image that everything related to him is worthy of respect (which, if not appreciated, the person concerned can lose face). That is, this strategy represents the desire to be liked by others.

According to Yule (2006: 111), positive politeness refers to a speech strategy by highlighting closeness, intimacy, good relations between speakers and speech partners; 
3) negative politeness strategies. This politeness strategy in speaking to keep a negative face. A negative face is a person's self-image related to actions that ones to be free or undisturbed (which, if blocked, the person concerned can lose face). According to negative politeness refers to the strategy of speaking by showing the existence of social distance between the speaker and the speech partner (Yule, 2006:112). ; 4) vague strategy (of the record) or conveying unclear signals; and last, 5) strategy of not commenting or not speaking.

\section{B. RESEARCH METHOD}

The type of research used is pragmatic research with qualitative and quantitative approaches. The research population is all utterances in Whatsapp conversations in the college, high school, and junior high school groups. The sample of this study consisted of three groups: one group university level, one group high school level, and one group junior high school level. The sampling technique used was purposive sampling because not all data represent complete conversations. This technique is used so that researchers can obtain a representative sample. The data analysis technique is processed based on Miles, Huberman \& Saldana (2014, p. 14) with stages 1). Coding based on politeness characteristic indicators, at this stage, the researcher encodes Whatsapp group conversation data at each level of education based on politeness characteristic indicators Brown Levinson, 2). Then the next step is to calculate the frequency of occurrence of each politeness strategy in each Whatsapp conversation group 3). The last stage is the interpretation of politeness strategies in Whatsapp using the same approach as the Makassar cultural perspective.

\section{FINDINGS AND DISCUSSION}

\section{Findings}

Data analysis found that teenagers prefer to use three types of the five politeness strategies in their conversations on WhatsApp. These were bald on record, positive, and negative politeness strategies. The table below shows the type and frequency of using politeness strategies from the teenagers at each level of education. 


\begin{tabular}{|c|c|c|c|c|c|c|c|c|c|c|}
\hline \multirow{2}{*}{\multicolumn{2}{|c|}{ Politeness Strategies }} & \multicolumn{6}{|c|}{ Level of Education of Speaker } & \multirow{3}{*}{$\begin{array}{l}\text { Sub- } \\
\text { Total }\end{array}$} & \multirow{3}{*}{ Total } & \multirow{3}{*}{$\begin{array}{l}\text { Total } \\
\text { Perc. }\end{array}$} \\
\hline & & \multicolumn{2}{|c|}{ Colleges } & \multicolumn{2}{|c|}{ High Schools } & \multicolumn{2}{|c|}{ Junior High Schools } & & & \\
\hline & & Freq. & Perc. & Freq. & Perc. & Freq. & Perc. & & & \\
\hline \multirow{3}{*}{$\begin{array}{l}\text { Bald on } \\
\text { Record }\end{array}$} & Questions & 10 & 6,45 & 8 & 5,16 & 45 & 29,03 & 63 & \multirow{3}{*}{108} & \multirow{3}{*}{69,68} \\
\hline & Reign & 8 & 5,16 & 11 & 7,10 & 15 & 9,68 & 34 & & \\
\hline & Ask & 8 & 5,16 & 2 & 1,29 & 1 & 0,65 & 11 & & \\
\hline \multirow{3}{*}{ Positive } & Joke & 19 & 12,26 & 9 & 5,81 & 0 & 0,00 & 28 & \multirow{3}{*}{40} & \multirow{3}{*}{25,81} \\
\hline & Identity & 5 & 3,23 & 2 & 1,29 & 0 & 0,00 & 7 & & \\
\hline & Attention & 5 & 3,23 & 0 & 0,00 & 0 & 0,00 & 5 & & \\
\hline \multirow{4}{*}{ Negative } & Apologies & 2 & 1,29 & 1 & 0,65 & 0 & 0,00 & 3 & \multirow{3}{*}{7} & \multirow{3}{*}{4,52} \\
\hline & Be Thankful & 3 & 1,94 & 0 & 0,00 & 0 & 0,00 & 3 & & \\
\hline & Questions & 0 & 0,00 & 1 & 0,65 & 0 & 0,00 & 1 & & \\
\hline & & & & & & & & & 155 & 100 \\
\hline
\end{tabular}

Table: Type and Its Frequency of Teenagers Politeness Strategies based on Their Level Education on Social Media WhatsApp

The result shows that teenagers from all levels of education use bald on record, positive, and negative politeness strategies in their conversation on WhatsApp, respectively. It appears that teenagers at junior high schools are the highest users of the bald on record strategy in the form of questions. However, teenagers from colleges use more positive politeness strategies in-jokes.

\section{Discussion}

\section{Bald on record}

Bald on record strategy is defined as the most direct way of saying something (Brown \& Levinson, 1987). There are three ways of using this strategy from the teenagers of all education levels.

\section{Questions}

The table above shows that the use of bald of record strategies in the form of questions was the most widely used in Whatsapp conversations at the junior high school level, while those who used the method the least were at the high school level. This shows that junior high schoolers have a relatively high sense of curiosity. Someone at the junior high school level has entered his early teens. The Indonesian Ministry of Health's data and information center related to adolescent reproductive health (2015) said that one of the distinctive characteristics possessed by adolescents is having a high curiosity.

Examples of bald of record use on record politeness strategies in the form of questions in Whatsapp conversations by each level of education can be seen in the following utterances. Utterances from college's student represent by number (1), High Schools 
student's number (2), and Junior High Schools student's number (3) below:

Extract conversation from college's student's (1):

(1). A: "Di kampusmako?" 'Are you on campus already?'

Extract conversation from High Schools student's (2):

(2). A: "Wee tamae mkohh" 'Where have you been?'

Extract conversation from Junior Schools student's (3):

(3). A: "Di mana ko?" 'Where are you?'

B: "Di rumah" 'At my house'

The three utterances above are included in the bald on record politeness strategy. The three of them asked directly without using a preamble. Each of these utterances uses the pronoun "-ko, " indicating that they have a close relationship with their friends. However, in Bugis-Makassar's culture, the use of the pronominal "-ko" is a form of impoliteness in a person's utterance. So, it can be said that the three examples of statements above include a declaration that is impolite.

\section{Reign}

The results in the table above show that direct politeness strategies in the form of commands were the most widely used in Whatsapp conversations at the junior high school level, while those who used the technique the least were at the college level. This shows that students still have a high enough ego at the junior high school level that they like to command others.

Examples of bald use on record politeness strategies in the form of ordering in Whatsapp conversations by each level of education can be seen in the following utterances. Utterances from college's student represent by number (4), High Schools student's number (5), and Junior High Schools student's number (6)

Extract conversation from college's student's (4):

(4). A: "Kirimmi cepat videonya" (Quickly send the video)

Extract conversation from High Schools student's (5):

(5). B: "We... besok cepatmako ke sekolah" 'Well...You have to hurry to school tomorrow.'

Extract conversation from Junior Schools student's (6):

(6). C: "Oe pergiko ke lapangan e" 'Ehh... go to the yard...!'

The three statements above are included in the strategy of bald on record politeness. The three ruled directly without using pleasantries or politeness markers before ordering. Small talk or features when ordering are significant so that the utterance partner can well 
receive the command. In line with the results of Saeful's research (2021), one strategy in ordering so that the power can be received well by the utterance partner without threatening the faces of both parties is to use politeness markers. The politeness markers referred to in Bugis language are addampengengka (forgive me), tulungngak (please), tabek (sorry).

\section{Asking}

The table above shows that the use of bald of record in the form of requests was the most widely used in Whatsapp conversations at the college level, while those who used the technique the least were at the junior high school level.

Examples of the use of bald on record politeness strategies in the form of asking in Whatsapp conversations by each level of education can be seen in the following utterances. Utterances from college's student represent by number (7), High Schools student's number (8), and Junior High Schools student's number (9)

Extract conversation from college's student's (7):

(7). A: "Club Dulue" 'Let us go to the club, guys'

Extract conversation from High Schools student's (8):

(8). B: "Respond dulu nde" 'Reply me...!'

Extract conversation from Junior Schools student's (9):

(9). C: "Kasi ka Waldi ee.. audio nu" 'Give me your audio, Waldi'

The three above statements use Bald on Record strategies and are less polite. This is indicated by using the utterance asking directly without using pleasantries first. So that the three utterances can be said to be less polite because they seem forced, do not give a choice to the utterance partner or to his friend.

\section{Positive Politeness Strategy}

The Following is a discussion about positive politeness strategies, as shown in the table above. It seems that university students, senior and junior high school students have their way of interacting with their friends. As shown in the examples below.

\section{Jokes}

The table above shows that positive politeness strategies in-jokes were the most widely used in college-level Whatsapp conversations. In contrast, they did not use this strategy in the junior high school-level discussions. This shows that they have a relatively high sense of humor at the university level. Although this strategy seems impolite, it is a form of intimacy shown through jokes. So, this strategy is one way to strengthen friendships. This is in line with the opinion of Spero (2013), which says that laughter 
occurs when each individual feels comfortable with each other and when they feel open and accessible. The more laughter, the stronger the bonds in a group.

Examples of positive politeness strategies in the form of jokes in Whatsapp conversations by College students and High School students' education levels can be seen in the following utterances. Utterances from college's student represent by number (10) and High Schools student's number (11).

Extract conversation from college's a student (10):

(10). A1: "Teman orang kayaku" 'This is my rich friend..'

A2: "Mirip Satek cuman beda nasibki" 'Similar to Satek's face, but they have different fates.'

In the context of the conversation above, "A" sent a photo of a girl from Law School who has just finished her exam results. Incidentally, the image is similar to Satek face.

The above statement includes a positive politeness strategy in the form of a joke. The utterance with the tricks designs directly shows the intimacy between the speaker and the utterance partner. In this conversation, $\mathrm{A}$ is joking by using a humiliating technique of touches of humor. This can be seen in A's utterance, "Similar to Satek face but different fates." He compares his friend's face to Satek, but he reaches social status. This might offend others, but because Sate' and A have a close relationship, A's utterance has only become a laughing stock for the group.

Extract conversation from High Schools student's (11):

(11). B: “Laki-laki jam seven perempuanna jam 12" 'For boys, it's 7 o'clock, while for girls it's 12 o'clock.'

The context in the above utterance, all students should go to school to clean up in their classroom. At that time, one of the students asked what time they should go to school. So, B immediately said, "Men at 7 o'clock and women at 12 ", meaning that men must go to school at seven while it is okay for women to go to school at 12 o'clock.

This statement is included in the positive politeness strategy in the form of humor. The use of humor techniques in the utterances can make friends laugh aloud.

\section{Identity}

The table above also shows social identities in their conversation. The results of the study show in graph two that the use of positive politeness strategies in the form of identity is the most widely used. Meanwhile, at the junior high school level, they did not use positive politeness strategies in identity in Whatsapp conversations.

Data Whatsapp conversations at college's students level use various forms of greeting to show identities, for example, Beb, Bro, and Chika. So it can be said that the level of 
solidarity and intimacy owned at the university level is quite good. This is in line with Ermitati's opinion (2012, p. 5) that speakers can express appreciation, solidarity, kinship, and intimacy towards their interlocutors by using different greeting words.

Examples of positive politeness strategies in the form of identity in Whatsapp conversations by College students and High School students' education levels can be seen in the following utterances.

Utterances from College's student represent by number (12) and High Schools student's number (13).

(12). A: "Masya Allah, makasih banyak Bebku. Semoga dimudahkan juga urusannya sama Allah." 'Masya Allah, thank you very much my Baby. May Allah make things easy for you'

Extract conversation from High Schools student's (13):

(13). B: "Jam 7 berangkat mi besok Cika'" 'Tomorrow you depart at 7 Cika'

The two statements above include positive politeness strategies in the form of identity. This is indicated by the use of greetings in the utterances. Greeting "Bebku" at the college level and the greeting "Cika"' at the high school level utterances is a form of showing the speaker's closeness to the utterance partner.

\section{Attention}

The results show in the table above that positive politeness strategy in attention was only used in college-level WhatsApp conversations. Positive politeness strategies in the form of engagement used in college-level discussions show that the level of sensitivity at that level is higher than at the level of education below it. The sensitivity shown in the form of attention is one of the attitudes that is reflected in the Business concept according to Gusnawaty \& Nurwati (2019), namely the idea of sipakatau (mutual respect), sipakaraja (mutual respect), and sipakalebbi (mutual glorification).

Examples of positive politeness strategies in the form of attention in Whatsapp conversations by College students' education levels can be seen in the following utterances. Utterances from college's students represent by number (14).

Extract conversation from college's student's (14):

(14). A: "Semoga bisa S.S. tahun ini semuanya teman-teman, semangat"

'I hope all of you could finish your school this year, friends'

The above statement includes a positive politeness strategy in the form of attention. This is marked by giving prayers and encouragement to friends. This attention shows the closeness between the speaker and the utterance partner. 


\section{Negative Politeness Strategy}

\section{Apologizing}

The results (Table above) above show the negative politeness strategy of apologizing used in college-level Whatsapp conversations. This indicates that they have a reasonably high sensitivity compared to other levels of education. This is under the definition of sensitivity (KBBI, 2016) which means easy to feel.

Examples of negative politeness strategies in the form of apologizing in Whatsapp conversations by College students and High Schools students' education levels can be seen in the following utterances. Utterances from college's student represent by number (15) and High Schools student's number (16).

Extract conversation from college's student's (15):

(15) A: "Sorry Bro, baruka bangun, capek sekalika seharian dari pagi pp RS." 'Sorry, Bro, I just woke up. I'm fatigued from going back and forth to the hospital.'

Context: The Whatsapp conversation was related to the graduation moment of one of his friends. A did not attend his friend's graduation. After all, he was fatigued because his family was sick at the hospital. The above statement includes a negative politeness strategy by apologizing. The apology strategy is seen in A's utterance. The use of A's phrase with the word "sorry" shows that A feels sad and regrets not attending his friend's graduation because of his situation. The term "Bro" in A utterance is a marked closeness.

Extract conversation from High Schools student's (16):

(16). A: “Maff di.. minroa nakke?" 'Sorry, I went back early.'

Context: conditions at that time, all students in the group were supposed to come to school for community service (cleaning class) as they promised, but many of them couldn't come even though they came to school, still going back early.

The utterance (16) shows regret to her friend because he could not wait long at school to do the cleaning and go back early. He realizes his fault and says sorry. This behavior is indicative of negative politeness strategies. The speaker, in his utterance, apologized to the interlocutor for leaving school so that he did not participate in community service. The speaker speaks the word sorry as an expression of guilt to his friends.

\section{Thanking}

The results (Table above) show that negative politeness strategies in apologizing were used only at the conversation Whatsapp college level. This indicates that they have a high 
sense of solidarity at the university level by using the word thank you so that their friendship remains harmonious. This is in line with Allen's opinion $(2001$, p. 2) that the expression of gratitude in daily communication is one example of the many politeness strategies that humans use to cultivate and maintain social relationships.

Examples of negative politeness strategies in the form of thanking in Whatsapp conversations by College students' education levels can be seen in the following utterances. Utterances from college's students represent by number (17) below.

(17). A: "Terima aksih sodara" ' Thank you friend'

The above statement includes negative politeness strategies. This is indicated by gratitude, which shows that the speaker is very happy or grateful for what the interlocutor has done to him.

\section{Questions}

The results (Table above) showed that negative politeness strategies in the form of questions beginning with the words 'Assalamualaikum' and 'Tabe' were only used in high school level Whatsapp conversations.

Examples of negative politeness strategies in the form of Whatsapp conversations by high school students' education levels can be seen in the following utterances. Utterances from High School student's represent by number (18) below.

\section{(18). A: "Assalamualaikum tabe' jadijaki pergi di sekolah yah atau tidak?"}

The above statement uses a negative politeness strategy. This can be seen from the word tabe', which means excuse me. For the Bugis-Makassar people, the word tabe' is a word that shows a high level of politeness.

There are similarities and differences at each level in using the three strategies. They have in common is that the bald on record politeness strategy of commanding, asking, and asking is used by all levels of education. The difference is that college and high school only use positive politeness strategies, in-jokes, and highlighting identity. In contrast, positive politeness strategies in the form of attention are only used at the college level. Then the second difference, negative politeness strategies in the form of apologies, are only used by college and high school. Negative politeness strategies in the form of questions are only used by high school. Lastly, negative politeness strategies in thanking are only used at the college level.

The findings above show that each level of education has a different level of 
politeness. Politeness strategies that tend to be used at each level of education are bald on record politeness strategies and positive politeness strategies. These show that the utterance in the Whatsapp conversation group at all levels of education tends to be less polite. While the least used politeness strategies are positive politeness strategies in the form of attention and negative politeness strategies in the form of thanks, apologizing, and questions. This strategy is only used at the tertiary and high schools, but the tertiary level is more likely to use this strategy than the high schools. These showed that politeness at the tertiary level is better than high school and junior high school education. The findings align with the assumption that the more educated, the more polite.

\section{CONCLUSION}

Based on the discussion results above, the utterances in conversations group Whatsapp at all levels of education, namely: college, high school, and junior high school, tend to use bald on record strategies and positive politeness strategies. These showed that utterance in the group Whatsapp at all levels of education tends to be less polite, especially if the speaker and listener have close social distance.

Another finding showed that junior high school students never used or paid attention, apologized, and thanked them in their utterance. High school students have used the word "sorry" in their communication, and college students have explored all three: apologizing, thanking, and paying attention to the interlocutor.

Politeness strategies in the form of attention, apologizing, and gratitude signifies a person's sensitivity or empathy for others. This is important for all of us to pay attention to for life's benefit and social harmony. As the Bugis-Makassar cultural concepts of sipakatau (mutual humanity), sipakaraja (mutual respect), and sipakalebbi (mutual honoring). (Gusnawaty \& Nurwati, 2019).

The research has been done on Whatsapp conversational politeness strategies based on education level. Recommendation: 1) Research related to this topic still needs to be studied more deeply. 2) Parents, teachers, and all stakeholders should pay attention to the language behavior of the young generation, especially Junior High School and below, due to these findings. 3) The researcher suggests seeing it from a gender perspective for colleagues interested in exploring similar issues. The last but minor recommendation is 
to examine several schools and universities in Indonesia to understand the young generation's politeness strategies while interacting online.

\section{REFERENCES}

Allen, S. (2001). The Management of the communication of the Japanese speech act of gratitude. Asea E-Journal of Asian Linguistics and Language Teaching.

Brown, \& Levinson, S. C. (1987). Politeness: Some universals in language usage. Cambridge University Press.

Chandra, O. H. (2021). Politeness in the use of language in social media. E3S Web of Conferences, 317, 02027. https://doi.org/10.1051/e3sconf/202131702027

Ermitati. (2012). Antologi hasil pelitian bahasa dan sastra: Kata sapaan dalam bahasa Kubu. Kantor Bahasa.

Gunarwan, A. (2007). Implikatur dan kesantunan berbahasa: Beberapa tilikan dari sandiwara ludruk. In Y. Nasanius (Ed.), PELLBA 18 (pp. 85-119). Pusat Kajian Bahasa dan Budaya Unika Atma Jaya.

Gusnawaty, G., \& Nurwati, A. (2019). A learning model of bahasa Indonesia as a foreign language based on local intercultural politeness. Jurnal Cakrawala Pendidikan, 38(1), 141-155. https://doi.org/10.21831/cp.v38i1.23022

Hootsuite. (2021). Digital 2021 Indonesia.

Husna, L. L., \& Arief, E. (2020). Strategi kesantunan bertutur mahasiswa kepada dosen melalui komunikasi WhatsApp. Jurnal Pendidikan Bahasa Dan Sastra Indonesia, 9(4), 13. https://doi.org/https://di.org/10.24036/11072-019883

Kaplan, \& Haenlein. (2010). Users of the world, unite! The challenges and opportunities of social media. Bus Horiz, 53, 59-68.

Kasper, G. (2007). Locating politeness in interaction. Journal of Politeness Research, 115.

Miles, Huberman, \& S. (2014). Qualitative data analysis a methods sourcebook. Sage.

Mulyana, N. (2021). Politeness strategies on instagram: A cyberpragmatics perspective. Prosiding Seminar Nasional Linguistik Dan Sastra (Semnalisa), 978-602-5872-785, 200-206.

Nasrullah, R. (2015). Media sosial; Perspektif komunikasi, budaya dan sosioteknologi. Simbiosa Rekatama Media.

Purnamasari, R., Nurmansyah, N., \& Fitriani, I. (2021). Kesantunan bertutur mahasiswa dalam pembelajaran luring dan daring melalui aplikasi WhatsApp. Jurnal Ilmiah Ilmu Pendidikan, 4 no., 435-440.

RI, P. data dan informasi kementrian kesehatan. (2015). Situasi Kesehatan Reproduksi Remaja. Kementrian Kesehatan.

Saeful, M. (2021). Strategi kesantunan bahasa bugis dalam tindak tutur memerintah di Kecamatan Ujung Loe Kabupaten Bulukumba. JRIP, 1 No 2, 240-251.

Setiawan, Y. (2020). Pola kesantunan berbahasa antara mahasiswa dan dosen melalui media sosial "WhatsApp" di IAIN Takengon. Jurnal Komunitas Bahasa, 8 no.

Spero, D. (2013). Laughter: Is it really the best medicine?

Yaqien, I., \& Haeri, Z. (2021). Kesantunan berbahasa pada media jejaring sosial (WhatsApp) bahasa Indonesia di Kampus UTM Mataram. Jurnal Linguistik, Sastra, Dan Pendidikan, 6 no., 87-96.

Yono, D. (2021). Kesantunan berbahasa siswa SMP melalui media sosial WhatsApp: 
kajian pragmatik. Jurnal Inovasi Dan Riset Akademik, 2 no. 6, 849-856.

Yus, F. (2011). Cyberpragmatics: Internet-mediated communication in context. John Benjamins Publishing Company. 